segregates independently of the $\mathrm{ABO}$, Rhesus, MNSs, Kell, Lewis red cell (and ABH secretion), Duffy and Kidd blood group systems; nor is the character partially sex-linked.

These findings will be reported in detail at a later date.

South London Transfusion Centre.

$$
\text { T. E. CleghorN }
$$
Sutton, Surrey.

\section{Glutathione Stability of the Erythrocytes in Iranians}

HeMOLYTIC reactions following the ingestion of drugs such as primaquine and the broad bean (Vicia faba) have been shown to be due to an inherited abnormality of the erythrocytes which can be detected by an in vitro glutathione stability test devised by Beutler'1. The use of this test in surveys has established that the incidence of the defect varies with peoples and race. American Negroes, Sephardic Jews and Sardinians have a much higher incidence of sensitive individuals than Ashkenazio Jows or American Caucasians. Beutler has recently reviewed the subject ${ }^{2}$. Many cases of favism have been seen locally during the past fow years, and it was reasonable to assume that a survey of the glutathione stability of the erythrocytes in Iranians would show the presence of the abnormality in this area.

The survey group consisted of 556 Moslems who were members of the medical, nursing and ancillary staff at our two institutions. Only one member of a family was sampled. However, because consanguinity is quite common in Iran, it was impossible to be sure of eliminating children of first-cousin marriages. Persons of Jewish, Armenian, Assyrian or Zoroastrian origin were not in sufficient number for evaluation. These groups, along with various tribes, are being studied, and will be the subjects of later reports. The blood samples were collected into an acidcitrate-dextrose solution; glutathione determinations and the glutathione stability test were performed by the standard technique usually on the same day or within $24 \mathrm{hr}$. of collection. Hæmatocrit values were also determined.

Since it has been shown that the gene which controls the abnormality is probably sex-linked, the results

Table 1. ANalysis of BLood GLUTATHIONE-LEVELS BEFORE AND AFTER INCUBATION WITH ACETYLPHENYLHYDRAZINE (THE GLUTATEIONF

\begin{tabular}{|c|c|c|c|c|c|c|}
\hline & & & & & & \\
\hline & $\begin{array}{l}\text { No. of } \\
\text { subjects }\end{array}$ & & $\begin{array}{l}\text { Range of } \\
\text { Values }\end{array}$ & Mean & & S.E. \\
\hline nsi & 3 & before & & $33 \cdot 9$ & $8 \cdot 3$ & 1 \\
\hline Lex & $\begin{array}{r}323 \\
(257\end{array}$ & & $\begin{array}{c}0 \cdot 2- \\
40 \cdot 0-1\end{array}$ & $\begin{array}{r}5 \cdot 1 \\
64 \cdot 1\end{array}$ & $\begin{array}{r}4 \cdot 9 \\
12 \cdot 3\end{array}$ & $\begin{array}{l}0.8 \\
0.8\end{array}$ \\
\hline $\mathrm{ma}$ & & & 33 . & 54 & $12 \cdot 5$ & \\
\hline $\begin{array}{l}\text { Sensiti } \\
\text { fems }\end{array}$ & 12 & & & & & \\
\hline & 86 & $\begin{array}{l}\text { after } \\
\text { before }\end{array}$ & $\begin{array}{r}0 \cdot 7-27 \cdot 1 \\
36 \cdot 3-124 \cdot 0\end{array}$ & $\begin{array}{l}\mathbf{1 4} \cdot 2 \\
66 \cdot 6\end{array}$ & $\begin{array}{r}9 \cdot 4 \\
15 \cdot 6\end{array}$ & $\begin{array}{l}2 \\
1\end{array}$ \\
\hline & & after & $32 \cdot 8-109 \cdot 2$ & 60.5 & $13 \cdot 2$ & \\
\hline
\end{tabular}

All values are in $\mathrm{ngm}$. glutathione per $100 \mathrm{ml}$. red blood cells. * The numbers in brackets are the number of samples tested both before and after treatment with acetylphenylhydrazine ; the remainder of the nonsensitive persons were tested only after treatment with

Table 2. Distribution OF GLUTATHIONE-LEVEIS (IN MGM. GLUTA THIONE PER 100 ML. RED BLOOD CEILS) AMONGST SENSITIVF PERSON AFTER INCUBATION WITH ACETYLPHENYLHYDRAZINE

$\begin{array}{lccccc}\begin{array}{l}\text { Range of } \\ \text { values }\end{array} & 0 \cdot 1-5 \cdot 0 & 5 \cdot 1-10 \cdot 0 & 10 \cdot 1-15 \cdot 0 & 15 \cdot 1-20 \cdot 0 & 20 \cdot 1-30 \cdot 0 \\ \begin{array}{l}\text { No. of } \\ \text { males }\end{array} & 22 & 8 & 3 & 2 & 0 \\ \begin{array}{c}\text { No. of } \\ \text { females }\end{array} & 2 & 3 & 1 & 0 & 6\end{array}$

were calculated independently for the two sexes. Using as the criteria of sensitivity to the glutathione stability test all values of less than $30 \mathrm{mgm}$. glutathione per $100 \mathrm{ml}$. red blood count after incubation with acetylphenylhydrazine ${ }^{3}$, there were 35 sensitive males out of $358(9.8$ per cent) and 12 sensitive females out of 198 (6. per cent). This difference of incidence between the males and females in this series is not statistically significant $(P>0 \cdot 10)$. Table 1 gives an analysis of the levels of glutathione in the erythrocytes before and after incubation with acetylphenylhydrazine and Table 2 shows the distribution of post-incubation glutathione-levels among the sensitive individuals. As previously described by other workers, ${ }^{4}$, sensitive males gave lower post-incubation glutathione-levels than females.

Having thus established an overall incidence of 8.5 per cent of sensitive individuals, the subjects were analysed according to place of birth. The results were as follows : Shiraz area 275, rest of Fars (the province in south-west Iran of which Shiraz is the chief town) 89, Bushire 5, Teheran region 53, Azerbaijan 8 , Caspian sea area 12, Khohrasan 15, Kerman 4, Kurdistan 12, Bandar Abbas 1, Khuzistan 18, Yazd 26, Isfahan and province 31, born of Iranian parents outside Iran 7. Of the total of 47 sensitive persons, 26 were born in Shiraz (that is, an incidence of 9.5 per cent in this area), 10 were born in the rest of Fars and 11 were born in the rest of Iran. Though the number of subjects born outside Shiraz constituted slightly more than half of the series, they were too spread out over Iran to allow comparison with the Shiraz group. However, it appears that persons sensitive to the glutathione stability test are to be found in the Moslem population throughout Iran.

At the same time as this survey was performed, a number of other genetically determined characteristics were also examined. A statistical analysis of the $\mathrm{ABO}$ and $\mathrm{Rh}$ data revealed that the survey group represented a good random selection of individuals. The results of these and other blood anthropological studies will be presented later.

We gratefully acknowledge the assistance of Drs. M. Gueramy and S. Khajeh-Nassiri, Messrs. A. Khodadoost, M. Mogaddam, K. Samii, M.Shushtarian and Miss F. Rahami. Part of the expenses of this work was defrayed from a grant from the Wellcome Trust to one of us (D.G.W.).

Department of Biochemistry,

D. G. WALKER

Faculty of Medicine,

University of Shiraz.

Department of Pathology,

J. E. BOWMAN

Shiraz Medical Center,

The Nemazee Hospital, Shiraz, Iran.

Beutler, E., J. Lab. and Clin. Med., 49, 84 (1957).

${ }^{2}$ Beutler, E., Blood, 14, 103 (1959).

Szeinberg, A., Asher, Y., and Sheba, C. Blood 13, 348 (1958).

Szeinberg, A., Sheba, C., and Adam, A., Blood, 13, 1043 (1958).

\section{Hamoglobin Pattern of the Cyclostome Pertromyzon planeri during the course of Development}

'Two hæmoglobin components have been demonstrated by starch gel electrophoresis in both larval and adult forms of Petromyzon planeri ${ }^{1}$. Although the components are most clearly separated by electrophoresis in starch gel, separation has also been 